\section{RAJA ALI HAJI: PELINDUNG BUDAYA DAN PEMELIHARA BAHASA MELAYU}

\section{Alimuddin Hassan Palawa}

Fakultas Tarbiyah dan Keguruan UIN Suska Riau

\section{Abstract}

Raja Ali Haji: A Protective of Culture and the Preserver of Malay Language: when there is a study of the Malay language, figures and efforts that are always mentioned is what is done by some Western scholars, especially the preparation of dictionaries, for example thomas bowrey, werndly, $W$. van RECs, W. Marsden, R. Eysinga and J. van J. Hollander. King Ali haji is known only as a scientist in the field of religion and Malay languages. Stature in the field of language is not widely known by the public. It turns out, the Raja Ali Haji has two monumental works in the field of languages, namely: Al-Bustan and The Book of Knowledge Katibin that recommended him as an expert on language and Malay culture. Two of these works are two of the earliest writings about Malay language study produced by the Malay people. However, the Raja Ali Haji is the child's degree of identity in the first malay who have attempted to explain the Malay grammar, writing procedures for Malay language in Arabic script (Jawi). then, the king ali haji was also the first person who has written a monolingual dictionary (eka language) in the Malay language among Malay tribe. From the two works mentioned above, Raja Ali Haji seeks earnestly and constantly develop and maintain the culture and language of indigenous Malay, so be dedicated bimself as a Malay linguists and cultural experts.

Keywords: Malay language, culture, Raja Ali Haji.

\section{Pendahuluan}

Dua karya Raja Ali Haji dalam bidang bahasa, yaitu Bustan alKatibin $^{1}$ dan Kitab Pengetabuan Bahasa, ${ }^{2}$ yang merefresentasikannya

1 Judul buku Bustanul Katibin diterjemahkan sendiri oleh pengarangnya dengan "Perkebunan Juru Tulis", sebagaimana terdapat dalam naskah Bustan al-
Katibin li al-Subyanal-Muta'allimin (Kitab Perkebunan Juru Tulis bagi Kanak-kanak yang Hendak Menuntut akan Belajar). Risalah setebal 56 halaman ini, tersimpan, misalanya di katalogus Yayasan Kebudayaan Indera Sakti Pulau Penyengat No. 19/1983. Untuk naskah kitab ini, terdapat dua salinan tulisan tangan yang masih ada, yaitu: Pertama, tersimpan di Perpusatakaan Nasional di Jakarta (ML 845), tertanggal 18 Zulkaidah 1267 (12 September 1851) manuskrip lainnya disebutkan oleh Van Ronkel merupakan copy dalam versi litografi). Sangat disayangkan, manuskrip ini telah rusak, sehingga tidak mungkin dibaca. Kedua, manuskrip yang tersimpan di Leiden (KI 410) tertulis pada tanggal 19 Zulkaindah 1267 (13 September 1851), dan kondisinya lebih baik. Bustan al-Katibin, menurut Hasan Junus, mulai ditulis Raja Ali Haji pada 1850, dan diselesaikan pada tahun berikutnya. Sementara itu, menurut Jan van der Putten dan Al Azhar, risalah ini ditulis untuk memenuhi permintaan YDM VIII Riau Raja Ali pada September 1851. Akan tetapi, karya ini baru dicetak seperempat abad belakangan, persisinya pada tahun 1875 di Riau dengan tekhnik litografi (cetakan batu), kemudian dicetak ulang di Singapura. Von de Wall telah melaporkan mengenai buku ini dalam Tajdschrit voor indische taal, Lendand Volkenkunde, IXI, bahwa buku ini telah dipergunakan di sekolah di Johor dan Singapura dengan hasil yang baik. Phlm. S. van Ronkel menerjemah karya Raja Al Haji ini dalam bahasa Belanda dan dimuat dalam Tijdschrift van het Bataviaasch Genootschap, XLIV, 1909. Karya ini disebut oleh Claudine Salmon, "sebuah karya asli yang lama dari luar Jawa haruslah dinyatakan, yaitu karya Raja Ali Haji yang bertahun 1857 dan judulnya Bustanu '-Katibin." Dalam surat pertamanya, tertanggal 16 September 1857, kitab Bustan al-Katibin dijadikan Raja Ali Haji sebagai balasan hadiah dalam mengawali persahabatnya dengan Von de Wall. Petikan suratnya berbunyi: "Amabakdu adalah kita menyatakan kepada sahabat kita yang kita sudah terima surat Undang2 yang sahabat kirimkan kepada kita itu. Maka sekarang kita ada kirimkan kepada sahabat kita satu kitab yang kita sendiri baharu karang, namanya Bustan katibin, ialah akan jadi hadiah kita kepada sahabat kita. Lihat, Hasan Junus, Raja Ali Haji dan Karya-Karyanya, (Pekanbaru: Pusat Pengkajaan Bahasa dan Kebudayaan Riau, 1996), hlm.155. Lihat juga Jan van der Putten dan Al-Azhar, "Introduction" dalam bukunya, Di Dalam Berkekalan Persababatan In Everlasting Friendship Letter From Raja Ali Haji, (Leiden: Departement of Languages and Culture of South-east Asia and Oceania University of Leiden, 1995), hlm. 13, 35 dan 133. Hasan Junus, Raja Ali Haji: Budayawan di Gerbang Abad XX, (Pekanbaru: Unri Press, 2002), hlm. 110; J. J. de Hollander, Pedoman Bahasa dan Sastra Melayu, (Jakarta: Balai Pustaka, 1984), hlm. 329; Mohd. Taib Osman, "Raja Ali Haji: A Figure on Transition or the Last of the Classical Puianggas?", dalam Bunga Rampai: Aspects of Malay Cultures, (Kuala Lumpur: Dewan Bahasa dan Pustaka, 1988), hlm. 78-82. 
sebagai seorang ahli bahasa dan budaya Melayu. Menurut beberapa orang sarjana, termasuk Teuku Iskandar, ${ }^{3}$ Bustan al-Katibin dan Kitab Pengetahuan Bahasa merupakan dua tulisan yang paling awal tentang kajian bahasa Melayu yang dihasilkan oleh "jati-diri" orang Melayu. Sebelumnya, memang telah ada kajian terhadap bahasa Melayu, khususnya penyusunan kamus yang dilakukan oleh beberapa orang sarjana Barat (Eropa), mula-mula dilakukan oleh sarjana Inggris, kemudian sarjana Belanda dan Perancis, misalnya Thomas Bowrey ${ }^{4}$ (1701), Werndly ${ }^{5}$ (1736), W. van Recs (1803), W. Marsden' ${ }^{6}$ (1812), R.

2 Kitab Pengetahuan Bahasa karya Raja Ali Haji ini judul lengkapnya adalah Kitab Pengetabuan Bahasa yaitu kamus logat Melayu Johor Pabang Riau Lingga. Meskipun, menurut Jan van den Putten, 'judul panjang" tersebut ditambahkan sepeninggalan pengarangnya, ketika diterbitkan oleh Ahmadiah Press di Singapura pada 1927. Penulisnya sendiri menekankan dalam suratnya kepada Von de Wall bahwa entrientri dalam kamusnya itu diambil dari bahasa Melayu, sebagaimana yang digunakan di Johor Riau dan Lingga. Untungnya, dua koleksi pribadi dari pemilik dari buku yang cukup penting ini sudah diterbikan. Pertama, versi tahun 1927 dari Kitab Pengetahuan Bahasa sekarang telah ada dalam edisi Latin: Kitab Pengetahuan Bahasa yaitu kamus logat Melayu Johor Pahang Riau Lingga, translitersi oleh Raja Hamzah Yunus, (Pekanbaru: Departemen Pendidikan dan Kebudayaan, 19861987). Kedua, edisi Jawi: Kitab Pengetahuan Bahasa yaitu kamus lughat Melayu JohorPahang-Riau-Lingga, diedit oleh Haji Wan Mohd. Shaghir Abdullah, (Kuala Lumpur: Khazanah Fathaniyah, 1996). Kedua edisi, menurut Jan van der Putten, pendistribusiaannya sangat terbatas. Jan van der Putten, "On Sex, Drug, and Good Manner: Raja Ali Haji as Lexicographer", Journal of Southeast AsIan Studies, Vol. 33, No. 3, October, 2002, hlm. 419

3 T. Iskandar, "Raja Ali Haji: Tokoh dari Pusat Kebudayaan Johor Riau", dalam Jurnal Dewan Bahasa, Disember 1984, hlm. 532-540

4 Ia adalah seorang berkembangsaan Inggris yang membuat kamus, $A$ Dictionary English and Malayo, Malayo and English. To which is added some short grammar Rules and Directions for the better observation of the propriety and elegancy of this language, London, 1701. Pieere Labrousse, "Sejarah Kamus Melayu dan Indonesia", dalam Daniel Perret dan Putri Rashidah Megat Ramli, Hubungan Budaya dalam Sejarah Dunia Melayu, (Kuala Lumpur: Dewan Bahasa dan Pustaka, 1998), hlm. 167.

${ }^{5}$ Ia adalah seorang warga Negara Swtzerland yang dilahirkan pada tahun 1694. Ia seorang pastor yang bertugas di Makassar dan seorang pengajar yang bertugas di Batavia. van Eysinga 7 (1833, 1836 dan 1839), J. J. Hollander (1845). Akan tetapi, Raja Ali Haji adalah sarjana anak jati diri Melayu pertama di Alam Melayu yang telah berupaya menjelaskan tata bahasa Melayu, tata cara penulisan huruf Arab bahasa Melayu (Jawi). Begitu pula Raja Ali Haji orang yang pertama kali menulis kamus monolingual (eka bahasa) dalam bahasa Melayu di kalangan puak Melayu. ${ }^{8}$ Dari kedua karya tersebut di atas, Raja Ali Haji berupaya dengan sungguhsungguh dan terus-menerus membina bahasa serta memelihara budaya

${ }^{6}$ Ia adalah orang yang kali pertama menyusun kamus besar, terbit pada tahun 1812 dan kemudian diterjemahkan ke dalam bahasa Belanda dan Perancis pada 1825 oleh C.P.J. Elout. Dalam versi bahasa Inggrisnya, A Dictionary of the Malayan Leanguage, (dalam dua bagian: Malayan dan Englisch; serta Englisch dan Malayan), London: 1812 [xvi + 590 halaman]. Versi Perancis dan Belandanya, Dictionnaire Malais, Hollandais et Prancais, traduit du Dictionnaire Malais et Anglais de W. Marsden, par C.P.J. Elout, Haarlen, 1825 [xxii +604 halaman]. Karya Marsdan ini, merupkan hasil kelanjutan dari tradisi pengkajian Inggris yang telah ada dan berkembang semasa Reffles bererada di Jawa, dapat dianggap sebagai kamus bahasa Melayu pertama yang lengkap. Karenanya, sarjana belakangan, sepert Pijnappel, Abbe Favre, Roorda van Eysinga, Crwfurd, merujuk kepada kamus Marsden yang menjadi sumber utama bahasa Melayu pada awal abad ke-19. Pieere Labrousse, "Sejarah Kamus Melayu dan Indonesia", dalam Daniel Perre dan Putri Rashidah Megat Ramli, Hubungan Budaya dalam Sejarab Dunia Melayu, hlm. 171-172.

Roorda van Eysinga awalnya adalah seorang tentara dan bekas prajurit Belanda, tetapi belakangan ia menggeluti dan menguasai bahasa Melayu. Kamusnya, Maleisch en Nederduitsch woordenboek, Batavia, 1825 [416 halaman]. Menurut pengakuannya, "Saya telah menyusun kamus ini berdasarkan penulisanpenulisan Melayu yang terbaik disertai tambahan daripada pengarang yang terkenal Mesekipun demikian, kamus Roorda van Eysinga ini sangat ringkas dan hampir tidak memuat contoh-contoh. Karenanya, jika dibandingkan dengan kamus yang dihasilkan oleh Marsden yang terbit pada waktu yang bersama, kamus Roorda van Eysinga tersebut tidak menojol.

${ }^{8}$ Mohd. Taib Usman, "Raja Ali Haji of Riau: A Figure of Tradisition or the Last of the Classical Pujanggas?” hlm. 51; lihat juga, Hashim bin Musa, The Bustan al-Katibin and the Kitab Pengetabuan Babasa of Raja Ali Haji of Riau: Establishing the Islamic Scolarly Tradition of Languange Studies in the Malay World", Makalah (belum diterbitkan), hlm. 1. 
dan adat Melayu, sehingga ia mengukuhkan dirinya sebagai ahli bahasa dan budayawan Melayu.

\section{Bustan al-Katibin dan Kitab Pengetahuan Bahasa: Islam dan Arabic Oriented}

Dalam pandangan Raja Ali Haji, sebelum memelihara budaya dan adat, ia terlebih dahulu membenahi "infrastruktur" budaya dan adat itu sendiri, yaitu bahasa Melayu. Artinya, seseorang dapat dikatakan berbudaya dan beradab kalau sebelumnya memiliki budi dan bahasa. ${ }^{9}$ Bahkan dengan tegas ia menyatakan dalam karyanya, Gurindam Duabelas, "Jika hendak mengenal orang yang berbangsa; lihatlah kepada budi dan bahasa". Raja Ali Haji memperlihatkan gagasannya mengenai makna penting bahasa dalam tradisi Islam, dan pada waktu yang bersamaan ia mengungkapkan pemikirannya tentang hubungan yang jalin-berkelindan antara bahasa dan moral, ${ }^{10}$ dan pesan-pesan ilmu agama, seperti termaktub dalam "Muqaddimah" Bustan al-Katibin:

Adab dan sopan itu daripada tutur kata juga asalnya, kemudian barulah kepada kelakuan... apabila berkehendak kepada menurut ilmu dan berkata-kata yang beradab dan sopan, tidak dapat tidak mengetahuilah dahulu ilmu yang dua iaitu ilmu wa lkalam. Adapun kelebihan ilmu wa l-kalam amat besar sehingganya mengatakan sebagian hukuma' segala pekerjaan pedang boleh dibuat dengan qalam, adapun pekerjaan kalam

${ }^{9}$ Hasan Junus menyebutkan bahwa kata budi kerap pula disejajarkan dengan kata bahasa, sehingga melahirkan sebuah konsep pelajaran tantang bahasa yang sekaligus berarti pendidikan budi pekerti. Pengertian budi bahasa inilah yang kelak tambah jelas sosoknya dalam pengertian adat, yang merupakan aturan-aturan baku tentang itu semua. Dalam mempertegas ungkapannya ini, Hasan Junus menyitir ungkapan Ali bin Abi Thalib, "bahasa yang rusak menggambarakan akhlak yang rusak". Hasan Junus, Raja Ali Haji: Budayawan di Gerbang Abad XX, hlm. 94; lihat juga, Raja Ali Haji, Kitab Pengetahuan Bahasa, hlm. 216-218.

${ }^{10}$ Jan van der Putten, "On Sex, Drug, and Good Manner", hlm. 418. tiada boleh dibuat dengan pedang... Ada beberapa ribu dan laksa pedang yang sudah terhunus dengan segores kalam jadi tersarung. ${ }^{11}$

Karya Raja Ali Haji Bustan al-Katibin ditulisanya dengan sistimatis yang terdiri dari Muqadimah, berisi 30 bab $^{12}$ dan diakhiri dengan khatimah. ${ }^{3}$ Pada bagian "Muqadimmah" buku ini pengarangnya mengutarakan tantang keutamaan ilmu dan akal serta perilaku yang baik. Pada bagian ini juga dijelaskan tentang bentuk-bentuk dan tingkatan-tingkatan ilmu pengetahuan serta penjelasan tentang adab (etika) dan syaratnya. Misalnya, adab belajar antara seorang murid dengan guru. Raja Ali Haji mengatakan:

Syahdan jika tiada diperbuat oleh murid yang demikian itu jadilah kurang adab dan kurang berkatnya terkadang menjadi bahaya atas muridnya itu adanya. Bermula apabila sudah engkau

11 Raja Ali Haji, Busatan al-Katibin, hlm. 5.

12 Bagian kedua dari karya Raja Ali Haji ini terdiri dari 30 bab yang membahasan tentang: pasal 1 sampai 9 menjelakan tentang atauran-aturan sistem penulisan bahasa Melayu (huruf Jawi); pasal 10 sampai 13 menjelaskan kelompok kata-kata dalam bahasa Melayu didasarkan pada sistem dan termonologi bahasa Arab; pasal 14 sampai 15 menjelaskan unit-unit tata bahasa, yaitu kalimat, anak kalimat dan kata; pasal 16 sampai 28 berisi penjelaskan susunan kalimat menurut sintaksis yang beragam, yaitu bentuk-bentuk dan tipe-tipe kalimat, anak kalimat dan ungkapan yang bermacam-macam; pasal 29 sampai 30 membahas prinsipprinsip mengarang dari sudut pandang prioritas, etika dan kententuan yang ada, termasuk seni menulis surat dan istilah-istilah sapaan (memanggil seseorang). lihat Hasan Junus, Raja Ali Haji: Budayawan di Gerbang Abad XX, hlm. 110-111; Hasan Junus, Raja Ali Haji dan Karya-Karyanya, hlm. 158-159; Lihat juga, Hashim bin Musa, The Bustan al-Katibin and the Kitab Pengetahuan Babasa of Raja Ali Haji of Riau: Establishing the Islamic Scolarly Tradition of Languange Studies in the Malay World", hlm. 4-5.

${ }^{13}$ Khatimah yang berisi tiga nasehat: (1) hendaklah seorang murid mematuhi etika dan syarat dengan serius agar pada akhirnya berhasil memperoleh ilmu pengetauan yang berguna; (2) hendaklah seseorang mengiktui aturan-aturan dalam buku ini dengan urutan-urutan yang seksama; terakhir (3) hendaklah para penyalin naskah ini agar menyalin persis/ sama dengan aslinya, tanpa menambah beberapa bagian daripadanya. 
ketahui akan fadhilat dan adat serta sarat dan mani' talab al-ilm seperti yang telah lalu sebutannya itu maka patutlah bagi kamu menerima pelajaran pada ilmu-ilmu atau pada ilmu suratan Melayu dan hurufnya dan bahasanya serta aturannya. ${ }^{14}$

Sedangkan "syarat" kata Raja Ali Haji adalah antara "kamu dengan dirimu". Misalnya ia menyebutkan lima syarat menuntut ilmu, yaitu: 1. Al-Himmah, bersungguh-sungguh dengan ketetapan hati yang kuat ingin mendapatkan ilmu; 2. Al-Mudârasah, bersungguh-sungguh dalam belajar, dan tetap mempelajari kembali meskipun sudah dipahami; 3. Al-Mubâfą̧hah, dihafal ilmu yang sudah dibaca supaya mudah dijelaskan ketika dibutuhkan.; 4. Mu२âkarah, mendiskusikan dengan teman sesama pelajar untuk saling memberi tahu masingmasing yang terlupakan, sehingga terpatri kembali pengetahuan tersebut; 5. Muthâla'ah, mengkaji kembali ilmu yang sudah kita uji itu serta memikirkan kembali makna dan pemahamannya. ${ }^{15}$

Raja Ali Hají, sepertinya sangat dipengaruhi oleh bujjah al-Islam, al-Ghazali. Dalam tradisi keilmuan Islam, sebagaimana dipahami alGhazali, bahasa (baca: bahasa Arab) merupakan salah satu alat atau "ilmu tambahan" untuk menambah ilmu pengetahuan, khususnya yang bersumber dari Alqur'an dan Hadis Nabi, sekaligus sebagai sarana untuk meningkatkan keimanan dan ketaqwaan kepada Allah. Untuk itu, Raja Ali Haji menganggap bahwa perhatian terhadap ilmu tata bahasa sangat penting untuk diajarakan guna memperoleh ucapan yang tepat dan ungkapan yang halus. ${ }^{16}$

Kerananya, dalam melahirkan karya tentang tata bahasa Melayu itu, Raja Ali Haji sejauh mungkin mengikuti sintaksis bahasa Arab. ${ }^{17}$

${ }^{14}$ Raja Ali Haji, Busatan al-Katibin, hlm. 6.

${ }^{15}$ Raja Ali Haji, Busatan al-Katibin, hlm. 6.

${ }^{16}$ Maka sehubungan dengan ini, dalam, "Islam dan Kebudayaan Indonesia: Dulu, Kini dan Esok", Simposium Festival Istiglal I, Abdul Hadi W.M. mengungkapkan bahwa Raja Ali Haji sebagai bapak tata bahasa Melayu modern.

${ }_{17}$ Barbara W. Andaya \& Virginia Matheson, "Islamic Thougth and Malay Tradition - Writing of Raja Ali Haji of Riau (ca. 1809 - ca. 1873", dalam Perceptions of The Past in Southeast Asia, Singapura: Heineman Education Book [Asia] Ltd., 188
Meskipun Von de Wall, “di dalam berkekalan persahabatan”, selalu mendesaknya agar ini ia tidak terlalu bergantung pada model-model dan paradigma bahasa Arab. Akan tetapi, Raja Ali Haji tidak mengindahkan anjuran temannya, dan tetap melanjutkannya, sesuai dengan pendapat dan kenyakinannya, bahwa paradigma bahasa Arab dan metode-metode sarjana Arab adalah yang terbaik dan paling tepat untuk diterapkan dalam bahasa Melayu. ${ }^{18}$

Belakangan, kencenderungan Raja Ali Haji yang terlalu "arabic oriented" dan kuatnya pengaruh bahasa Arab dalam menulis karyanya, Kitab Pengetahuan Bahasa, mendapat tanggapan dan kritikan dari Za’ba. Pada dasarnya, Za'ba tidak setuju kalau Kitab Pengetahuan Babasa di sebut sebagai kamus, “... karena banyak melarat: jika demikian bukan lagi kamus bahasa namanya." Za’ba mengkritik karya Raja Ali Haji itu, "kaidah-kaidah dan sebutan-sebutan Arab banyak dipakainya pada nahwu dan lain-lain, padahal bahasa Melayu ada adatnya sendiri. ${ }^{19}$ Akan tetapi, menurut Riddell, kuatnya pengaruh bahasa Arab dalam bahasa Melayu Kitab tersebut tidak sepatutnya dipandang sebagai sesuatu yang buruk, justru sebaliknya sabagai sebuah kreasi yang beralasan, dan karenanya menjadi penting. ${ }^{20}$

1980, hlm. 122; Hashim bin Musa, The Bustan al-Katibin and the Kitab Pengetabuan Bahasa of Raja Ali Haji of Riau: Establishing the Islamic Scolarly Tradition of Languange Studies in the Malay World", hlm. 2

${ }^{18}$ Lihat, Virginia Matheson, "Revisting Riau with Knowlwdge: Teaching Text and Concept", dalam Jurnal Filologi Melayu, Jilid 4, (Kuala Lumpur: Perpustakaan Negara Malaysia, 1995), hlm. 40; bandingkan dengan artikel yang sama hasil terjemahan Al Azhar, Virginia Matheson, Virginia Matheson Hooker, Mengunjungi Riau Lagi Dengan Pengetahuan: Mengajarkan Teks dan Konsepkonsep", dalam Al Azhar dan ElmustIan Rahman (peny.), Kandil Akal di Pelatar Budi: Esai dan Renungan Budaya Persembahan Kepada Alm. Raja Hamzab Yusus, (Pekanbaru: Penerbit Yayasan Kata atas kerjasama Masyarakat Pernaskahan Nusantara Riau, 2001), hlm. 69.

${ }^{19}$ Mohd. Taib Osman, "Raja Ali Haji: A Figure on Transition or the Last of the Classical Puianggas?”, hlm. 56.

${ }^{20}$ Peter G. Riddell, "Literal Translation, Sacred Scripture and Kitab Malay", dalam Studia Islamika, Vol. 9, no. 1, 2002, hlm. 2. 
Raja Ali Haji, sesungguhnya, menurut Harimukti Kridalaksana, menyadari perbedaan antara bahasa Melayu dengan bahasa Arab. Mislanya Raja Ali Haji menyebutkan bahwa "dari bahasa Melayu tidak perlu dibaca majrur dan harf." Tidak itu saja, menurut Harimurti, pengkaji-pengkaji abad ke-20 ini, seperti halnya Teeuw dan Za'ba, pernah menyatakan bahwa Bustan al-Katibin dan Kitab Pengetahuan Bahasa tidak sistematis. Pendapat tersebut dibantah oleh Harimurti, seperti ungkapnya, "pengamatan yang lebih seksama terhadap karya tersebut tidak mendukung pendapat kedua sarjana besar tersebut. ${ }^{21}$

\section{Kitab Pengetahuan Bahasa: Makna Mufassar dan Pemeliharan} Bahasa

Raja Ali Haji menulis kamus ensiklopedis eka bahasa (monolingual)-nya, Kitab Pengetahuan Bahasa diawali pada 1857 hingga wafatnya pada 1873. Akan tetapi, Sayang sekali, karya ini hanya sampai pada huruf " $c a$ " (hurup keenam, berawal dari "alif", "ba", "ta", "nya", "jim", dan terakhir "ca"). Menurut Barbara dan Matheson, tidak selesainya karya ini mungkin dikarenakan kematian Raja Ali Haji. Pendapat Barbara dan Matheson ini, kemungkinan akan berbeda kalau surat-surat Raja Ali Haji kepada sahabatnya Van de Wall, belakangan diedit oleh Jan van de Putten dan Al Azhar, sudah ditemukan pada waktu keduanya menulis artikelnya, "Islamic Thougth and Malay Tradition - Writing of Raja Ali Haji of Riau (ca. 1809 - ca. 1873). Akan tetapi, belakangan Matheson sendiri mengemukan fakta-fakta yang mendukung bahwa Kitab Pengetahuan Bahasa tidak hanya sampai pada huru "ca". Mislanya, Matheson menyebutkan bahwa naskah Kitab Pengetabuan Bahasa karya Raja Ali Haji tersebut tersimpan dalam koleksi Raja Abdullah (Raja Aji Lah atau nama penannya Muhammaad Adnan), cucu Raja Ali Haji sendiri. Berdasarkan ingatan suadara

${ }^{21}$ Harimukti Kridalaksana, "Bustan al-Katibin dan Kitab Pengetahuan BahasaSumbangan Raja Ali Haji Dalam Ilmu Bahasa Melayu" dalam Tradisi Johor-Riau, hlm. 79-82; Hasan Junus, Raja Ali Haji Budayawan di Gerbang Abad XX, hlm. 114115. perempuan Raja Abdullah, lanjut Matheson, bahwa saudaranya itu memiliki perpustakaan yang berisi banyak sekali koleksi naskah-naskah dan buku-buku. Sayangnya, dua pertiga dari koleksi naskah-naskah dan buku-buku milik Raja Abdullah tersebut terbakar pada tahun 1924, termasuk ikut terbakar sebagian dari naksah Kitab Pengetabuan Bahasa, sehingga naskah terselamatkan hanya sampai hurup "ca" dan belakangan diterbitkan oleh al-Ahmadiyah di Singapura, 1928.22

Raja Ali Haji sendiri menyebutkan bahwa pada bulan Pebruari 1868 ia sudah menyusun daftar kata-kata sebanyak 3.730 (tiga ribu tujuh ratus tiga puluh) untuk kepentingan kamusnya, sebagaimana tertulis dalam suratnya "Wabakdubabu kemudian daripada itu adalah saya menyatakan, hal kamus yang saya perbuat maknanya mufassar itu sudahlah jadi kira2 tiga ribu tujuh ratus tiga puluh jadwal yang lain daripada makna mustaknya" Sementara itu pada waktu bersamaan untuk kepentingan kamus sahabatnya ada 2.600 kata telah dibuatnya. ${ }^{23}$

Begitu pula, dugaan bahwa Kitab Pengetahuan Bahasa tidak terbatas pada huruf "ca", dinyatakan sendiri oleh pengarangnya bahwa kamus yang dikarangnya itu telah sampai dua pertiga, ketika ia sudah merampung entri huruf "sin" dan akan masuk pada entir hurup " $p a$ ", sebagaimana dinyatakan dalam suratnya pada 20 April 1869:

${ }^{22}$ Memang data menyebutkan bahwa, seperti kata Hasan Junus, bahwa Kitab Pengetanan Babasa yang ada tercetak sekarang terdiri dari 87 pasal dan berisi 1.678 "kata kepala" (entri-entri). Lihat, Virginia Matheson, "Kisah Pelayaran ke Riau: Journey to Riau, 1984", dalm Indonesia Circle No. 36, March 1985, hlm. 14; U.U. Hamidi, "Naskah Kuno Daerah Riau: Gambaran Kegiatan Cendekiawan Melayu dalam Bidang Bahasa, Sastra dan Kemasyarakatan", dalam Masyarakat Riau dan Kebudayaannya, (Pekanbaru: Pemda Tk. I Riau), hlm. 149; Dugaan kebenaran pendapat terakhir ini didukung pertimbangan, sebagimana saran Hasan Junus, agar melihat: 1. Kitab Pengetahuan Bahasa, 1986-1987: 111; dan 2. Surat Raja Ali Haji kepada sahatnya pada Van de Wall pada 17 Safar 1287/19 Mei 1870. Hasan Junus, Raja Ali Haji: Budayawan di Gerbang Abad XX, hlm. 116; Jan van der Putten dan AlAzhar, Di Dalam Berkekalan Persahaban., hlm. 95.

23 Surta Raja Ali Haji, tertanggal, 9 Februari 1868, Jan van der Putten dan Al-Azhar, Di Dalam Berkekealan Persababatan, hlm. 76. 
Adalah kita maklumkan hal kamus sudah habis bab al-Sin, sudah berpindah kepada bab al-Pa. Kira2 kitab bab al-Pa barangkali tiga ratus atau lebih. Adapun akhir bab al-Sin tengah disurat oleh Abdullah ada kira2 tengah dua ratus, kira2 kita esok boleh dapat dua ratus. Adapun yang kita sendiri menyurat karangan itu pada bab al-Panya ada sudah tiga puluh dua logat serta makna mukhtasar. Syahdan jumlah kamus yang kita perbuat ini bahagi tiga, dua bahagian yang sudah, satu bahagian yang belum...24

Kamus karangan Raja Ali Haji memang tidak pernah selesai, mungkin karena keterbatas usia. Akan tetapi, dapat dipastikan bahwa kamus tersebut tidak hanya terbatas pada huruf "ca", bahkan hampir dirampungkan oleh pengarangnya dengan sudah masuk pada penulisan entri hurup "kaf" pada Mei 1870.25 Memang kamus ini, kata Henk Maier, "Betul tak selesai. Ibarat nasib setiap kamus: tak pernah bisa selesai." 26

${ }^{24}$ Jan van der Putten dan Al-Azhar, Di Dalam Berkekalan Persahaban., hlm. 78 dan 181. Menjelang akhir tahun 1869 atau tiga tahun menjelang wafatnya, bagian kamus yang ditulisnya itu sudah cukup lengkap, meskipun menurut "kamus yang tiada bersampaian" untuk dibawa pulang oleh muridnya, Raden Marta Admaja yang berasal dari Bandung. Jan van der Putten dan Al-Azhar, Di Dalam Berkekalan Persahaban, hlm. 86 dan 190.

${ }^{25}$ Raja Ali Haji Isi surat Raja Ali Haji tertanggal 19 Mei 1870 itu, diantaranya tertulis: “... Sayhdan empat hari ini terhenti menyurat bab al-Kaf, sebab kita lagi menambah2 pada yang tertinggal2 itu, disusup mana2 yang tertinggal itu pada kotak2nya. Pagi ini dapat satu pula bahasa teringgal pada bab al-Pa, yaitu bahasa parindun, yakni 'satu kelamin daripada hewan sama ada manusia atau hewan adanya". Jan van der Putten dan Al-Azhar, Di Dalam Berkekalan Persababatan, hlm. 95-96 dan 81. Lihat, Virginia Matheson, "Revisting Riau with Knowlwdge: Teaching Text and Concept", dalam Jurnal Filologi Melayu, Jilid 4, (Kuala Lumpur: Perpustakaan Negara Malaysia, 1995), hlm. 37 dan 39.

${ }^{26}$ Lihat, Hendrik Maier, "Raja Ali Haji, Arloji dan Mufassar", dalam Al Azhar dan ElmustIan Rahman (peny.), Kandil Akal di Pelatar Budi: Esai dan Renungan Budaya Persembahan Kepada Alm. Raja Hamzab Yusus, (Pekanbaru: Yayasan Kata kerjasama Masyarakat Pernaskahan Nusantara Riau, 2001), hlm. 179-180.
Perbedaan kedua kamus yang dibuat oleh Raja Ali Haji dan van de Wall, sebagaimana terbaca dalam surat Raja Ali Haji kepada sahabatnya pada tanggal 25 Muharram 1289/12 Maret 1872:

Bermula adapun kamus yang hendak diperbuat itu, yaitu bukannya seperti kamus yang seperti paduka sahabat kita itu. Hanyalah yang kita hendak perbuat bahasa Melayu yang tertentu bahasa pada pihak Johor Riau dan Lingga jua. Akan tetapi dibanyakkan bertambah di dalam qissah2 cerita2 yang meumpamakan dengan kalimat yang mufrad, supaya menyenagkan hati orang muda2 mutalaahnya, serta syair2 Melayu sedikit2. Di dalam hal itupun memberi mamfaat jua kepada orang2 yang mempikirkan perkataan dan makna bahasa Melayu pada orang2 yang bukan ternak Johor dan Riau dan Lingga. ${ }^{27}$

Menurut Raja Ali Haji, kamus yang diinginkan oleh sahabatnya itu tidaklah memadai, meminjam ungkapan Henk Maier, seolah-olah Von de Wall mau "mencekik" setiap kata Melayu, mendiamkan maknanya. Padahal bukankah setiap kata pantas dijelajahi seluasluasnya agar jangkauan makna ditentukan seteliti mungkin. ${ }^{28}$ Untuk itu, menurut Raja Ali Haji, ada kata-kata tertentu yang tidak bisa dipahami makna dengan tepat dan komprehensif kalau hanya diartikan secara mufrad, misalnya kata "semu", 29 tetapi harus diberikan makna mufassarnya, Raja Ali Haji menyatakan dalam suratnya:

${ }^{27}$ Lihat, Jan van der Putten dan Al-Azhar, Di Dalam Berkekalan Persababatan, hlm. 107.

${ }^{28}$ Hendrik Maier, "Raja Ali Haji, Arloji dan Mufassar", hlm. 177-178.

29 "Kemudian sava periksa2, dapat di dalam bab Sin suatu bahasa semu, dimaknakannya dengan bahasa Holanda dan huruf Holanda. Entahkan apa dimaknakannya itu karena bahasa Melayu semu tiada dapat dimaknakan dengan makna yang pendek akan sebenar2 maknanya, karena makna semu itu berhampirhampiran dengan makna 'aniaya' dan dengan makna 'tipu' dan dengan makna 'perdaya' dan dengan makna 'khianat' dan dengan makna 'merusakkan seorang'. Akan tetapi berbeda yang amat berlainan jika ditafsirkan dan tiada boleh mendapat serenar-benar maknanya, melainkan dengan dinyatakan segala kelakuan yang 
Ini ada bahasa Melayu serta maknanya ada sedikit panjang mufassarnya supaya menambah-nambahi terang pikir kita. Jika satu2 bahasa setengahnya, jika tidak diberi panjang sedikit mufassarnya barangkali gantunglah mafhumnya dan hakikatnya bersalahan. Jikalau diterangkan serta dibantu sedikit dengan ilmu nahu dan ilmu ma'ani, niscaya terlebih mafhumnya. Akan tetapi ada sedikit memperbuatnya terlambat, akan tetapi bukannya pula semuanya bahasa itu. Mana2 yang tiada patut dipanjangkan, yang tiada memberi faedah atau sedikit faedahnya, kita tinggal adanya..$^{30}$

Untuk itu, Raja Ali Haji tidak semata-mata ingin memberikan pengertian makna pada sebuah kata, tetapi juga memberikan pengajara kepada adat dan agama, maka kamus ensiklopedis monolingual, Kitab Pengetahuan Bahasa berbeda dengan kamus pada umumnya. Bahkan kamus yang disusunnya tersebut, menurut pengakuannya, berbeda dengan kamus yang sedang disusun oleh sahabatanya, Von de Wall 31 atas bantuannya. ${ }^{32}$ Letak perbedaan antara kamus yang dibuat oleh

berbuat dan kena perbuat baharulah putus maknanya. ... Syahdan pada kira2 saya apabila sahabat saya karang satu kitab yang tertentu perikat-ikatan bahasa dan perkataan, barangkali boleh mendapat terus sekali maknanya segala bahasa2 Melayu. Seperti semu tadi tiada dapat tiada kelakuan orang yang berbuat dan yang kena perbuat dinyatakan, baharu bernama semu." Jan van der Putten dan AlAzhar, Di Dalam Berkekalan Persahabatan, hlm. 56-57. 109

${ }^{30}$ Jan van der Putten dan Al-Azhar, Di Dalam Berkekalan Persahabatan, hlm.

${ }^{31}$ Mengenai kamus yang dibuat oleh Von de Wall yang teridiri dari pulah jilid, jilid pertamanya diterbitkan oleh Landsdrukkerij tahun 1872 di Batavia. Kamusnya dengan judul Meleisch- Nederlansch Woordenboek, op last van het gouvernement van Nederlandsch Indie samengesteld itu disambut dengan kritik tajam. Dan setelah satu tahun sepeninggalanya penerbitan jilad-jilid selanjutnya dihentikan. Naskah kamus Von de Wall yang berjilid-jilid itu tersimpan di Perpusatakaan Bataviaasch Genootschap. Lihat, Henk Maier, "Raja Ali Haji, Arloji dan Mufassar", hlm. 178179.

32 Dalam menyusun kamusnya, Van de Wall dibantu oleh Raja Ali Haji, khususnya dan disamping Haji Ibrahim. Sementara Raja Ali Haji sendiri bekerja untuk temannya itu dibantu oleh juru tulisnya Abdullah (putra Haji Ibrahim), dan 194
Von de Wall dan kamus yang dibuat Raja Ali Haji terletak pada penjelasan setiap "kata", sesuai dengan keinginan dan pendirian mereka masing-masing, Van de Wall lebih menghendaki kamus yang penjelasanya singkat (mufrad). Sebaliknya, Raja Ali Haji lebih menghendaki kamus yang memiliki tafsiran yang panjang (mufassar).

Raja Ali Haji menyadari bahwa keinginan dan keperluan sahabatnya itu berbeda dengan keinginan dan kepeluannya sendiri. Perbedaan keinginan kedua orang bersahabat ini dalam menyusun kamus, terlihat dari surat Raja Ali Haji: "Syahadan yang kita pun tahu juga yang maksud paduka bukannya perkara mufassar, hanyalah dikendaki pada sahabat itu hanyalah bahasa makna mufrad jua. Maka sudah juga sedia makna mufrad. Adapun makna mufassar pada kamus yang dicadangkan khas pada orang2 Melayu jua adanya." (surat 83, 1 Septemeber 1870). ${ }^{33}$ Maka sewaktu membantu sahabatnya, sejalan

anaknya sendiri Raja Hasan. Setidaknya, ada beberapa cara Von de Walla dalam membuat kamusnya hubungannya dengan bantuan sahabatnya, Raja Ali Haji. Misalnya, Von de Wall menyodarkan (meniggalkan) daftar kata-kata yang akan diartikan oleh Raja Ali Haji; atau cara lain, Raja Ali Haji sendiri yang menyusun kata-kata (bahasa-bahasa) Melayu yang diartikan sediri oleh Raja Ali Haji; dan/ atau kalau mereka bertatap muka Von de Wall “mencecar" Raja Ali Haji dengan katakata (bahasa-bahasa Melayu) untuk Raja Ali Haji jelaskan maknanya. Dalam membantu sahabatnya tersebut, diselah-selah kesibukanya waktunya mengajar, ia menyediakan waktau khusus, seperti ia sebutkan dalam suratnya [tertanggal, 27 Maret 1867]: "Lebih maklumlah tuan bukannya satu pekerjaan saya, sebab sepeninggalan tua balik ke Betawi itu maka datanglah anak-anak saya hendak mengaji ilmu fikih, ada yang hendak mengaii nahu. Jadi dibukalah pula semula pengajian seperti adat sehati-hari. Maka jadi banyaklah waktu saya di dalam pekerjaan. Maka adalah waktu yang saya tentukan untuk pekerjaan tuan itu yaitu pada malam. Maka jikalau tidak uzur, daripada pukul delapan sampailah pukul sebelas lebih kirang sedikit. Jika saya di Pengujan dapat juga pekerjaan tuan itu pada siang harinya sebentar2, demikianlah halnya. Lihat, Jan van der Putten dan AlAzhar, "Pendahuluan", hlm. 21-22. Mengenai bantuan Raja Ali Haji dalam menyusun kamusnya, mislanya lihat, Jan van der Putten dan Al-Azhar, Di Dalam Berkekalan Persababatan, hlm. 66 dan 69.

33 Lihat, Jan van der Putten dan Al-Azhar, Di Dalam Berkekalan Persahabatan In Everlasting Friendship Letter From Raja Ali Haji, hlm. 76. 
dengan perjalanan waktu, dalam dirinya terbentuk keinginan untuk membuat kamus sendiri yang lebih baik dari apa yang dibuat oleh sahabatnya demi kepentingan orang-orang Melayu. Meskipun konsekwensinya pembuatan kamus semacam itu memerlukan waktu yang lebih lama. Akan tetapi, menurut Raja Ali Haji, tidak semua kata harus dijelaskan secara mufassar. ${ }^{34}$

Menurut Harimurti Kridalaksana, dalam melihat karya Raja Ali Haji ini, terlihat ada keunikannya, yaitu metode leksikografis yang dipergunakannya bukan metode alfabetis, tetapi metode leksikografi bahasa Arab, seperti katanya, "metode leksikografis yang digunakan dalam kamus itu bukanlah metode alfabetis yang lazim dipergunakan sekarang, tetapi metode leksikografis yang menjadi dunia Arab selama berabad-abad." Raja Ali Haji sendiri tentu mengakui kemulian bahasa Arab sebagai bahasa Alqur'an dan kelebihan bahasa Arab bahasa ilmu pengetahuan. Bahkan, menurutnya dari bahasa Arab lahir berbagai cabang ilmu, seperti ilmu Bayan, ilmu Mantiq. Begitu pula pengakuannya terhadap kelebihan bahasa Arab dibandingkan bahasa lain sebagai bahasa ilmu, ia menyebutkan bahasa Arab itu sedikit lafadz dan hurufnya, tetapi banyak maknanya, misalnya bahasa Melayu "anakku benar perempuan seorang" ada kira-kira dua puluh huruf, tetapi kalau bahasa Arab cukup dengan "binti" yang hanya terdiri dari empat hurup..$^{35}$ Disamping itu, kata Harimurti Kridalaksana, bagi Raja Ali Haji pengajaran bahasa merupakan bagian yang akrab dari pendidikan budi pekerti dan agama." 36 Memang, salah satu tujuan utama penulisan kamus ini adalah guna membimbing mereka yang

${ }^{34}$ Jan van der Putten dan Al-Azhar, Di Dalam Berkekalan Persahabatan, hlm. 109; Hendrik Maier, "Raja Ali Haji, Arloji dan Mufassar", hlm. 177-178.

${ }^{35}$ Lihat, Raja Ali Haji, Kitab Pengetabuan Bahasa, hlm. 313.

36 Harimurti Kridalaksana, "Bustanul Kabitin dan Kitab Pengetahaun Bahasa- Sumbangan Raja Ali Haji dalam Ilmu Bahasa", dalam Tradisi Johor-Rian Kertas Kerja Hari Sastra 83, (Kuala Lumpur : Bahasa dan Pustaka, 1987), Cet, I, hlm. 79. berkeinginan menambah pengetahuan bahasa dan tata bahasa, agama dan perilaku yang benar dan terpuji. ${ }^{37}$

Karenanya, penyusunan kamus ensiklopedis monolingual Raja Ali Haji, Kitab Pengatahuan Bahasa adalah unik dari segi "metode" dan "materi". Keunikan tersbut, setidaknya disebabkan latar belakang dan tujuan Raja Ali Haji membuat kamus itu sendiri. Pertama, Raja Ali Haji tetap konsisten merujuk kepada metode bahasa Arab, karena ia ingin mencegah pengaruh bahasa Asing yang mulai menodai bahasa Melayu. Kedua, Raja Ali Haji memberikan uraian materi yang panjang terhadap sebuah kata, karena ia ingin agar kata tersebut dapat dipahami secara tepat dan benar, sekaligus memberikan pengajaran terhadap adat dan agama.

Upaya Raja Ali Haji untuk memberikan makna dan penjelasan secara mufassar pada Kitab Pengetahuan Bahasa menjadi relevan dengan tuntutan zamannya. Dalam pandangannya, kalau penggunaan bahasa Melayu tidak dijelaskan dengan baik dan terang, cepat atau lambat, masyarakat Melayu akan salah dalam penggunaannya. Pada waktu hidupnya saja, sudah ada kencenderungan yang keliru dalam penggunaan bahasa Melayu, dan ini tentu saja disesalkan oleh Raja Ali Haji, lantaran meniru bahasa Inggris dan Belanda. Pengabaian bahasa, menurut pendapatnya, berarti mengabaikan tradisi yang telah tertanam, yang tak terelakkan akan menghancurkan susunan dunia dan kerajaan. ${ }^{38}$ Penodaan bahasa Melayu dengan bercampur-baurnya, meniru penggunaan bahasa Asing, seperti tercermin dari penggunaan kata-kata, misalnya bilang (hitung) yang seharusnya cakap (bicara), dan kasib tahu yang seharusnya beri tahu, kata pasti dirubah penggungaanya menjadi musti, atau kalimat ini berapa harga? diganti menjadi ini berapa

${ }^{37}$ Barbara W. Andaya \& Virginia Matheson, "Islamic Thougth and Malay Tradition - Writing of Raja Ali Haji of Riau” hlm. 113.

38 Barbara W. Andaya \& Matheson, Islamic Thougth and Malay Tradition Writing of Raja Ali Haji of Riau hlm. 122. 
punya harga, dan masih banyak yang lainnya, menurut pengakuan Raja Ali Haji. 39

Pada kasus yang sama, pada 1862 Raja Ali Haji mendapatkan sebuah buku yang berjudul Kitab Loghat yaitu Kitab Menyatakan Bahasa Melayu dan Bahasa Nederland, terbitan P.P. Roorda van Eysinga (1855). Dengan suara lantang Raja Ali Haji memberikan kritikannya:

Campur baur bahasa dalam dan bahasa luar, dan campur baur lagi bahasa halus dan bahasa kasar, dan campur pula bahasa Arab. Entah siapa pengarangnya.... Dan lagi saya dapatkan pula di dalam kitab itu juga, pada bab Ta-nya dengan bahasa tak usah. Ini bahasa jika dituturkan dengan lidah, dan jika dengan surat2 tiada boleh begitu. Hendaklah dengan huruf tiada usablab. Dan jika dengan pertambatan perkataan, jika dengan lidah tak usablab engkau buat begitu, dan jika dengan huruf di dalam surat2 kepada sanak suadar2 'tiada usahlah adinda perbuat demikian itu' atau 'kakanda' atau 'tuan hamba'. Dan banyak lagi yang boleh dikiaskan dan diumpamakan adanya. ${ }^{40}$

Begitu pula, menurut Hasan Junus, telah terjadi salah kaprah karena kurang hati-hati mempergunakanyna dan tidak merujuk kepada sumber aslinya, misalnya penggunaan kata "serapah" yang seharusnya "seranah". Padahal, kata "serapah" sama artinya dengan "jampi" atau "mantera." Raja Ali Haji menjelaskan kata "jampi”: yaitu "seorang membacakan atas seseorang dari pada ayat Alqur'an dan atau doa-doa, isim-isim atau serapah-serapah karena obat kedatangan penyakit atau karena berkehendak sesuatu hikmah atau tangkal." Adapun "seranah" seperti jampi ketika seorang menghembuskannya kepada orang lain dari jarak jauh supaya orang itu bangkit birahi kepadanya. Kemudian dalam kosa kata bahasa Indonesia, kata "sumpah serapah" yang berarti "maki-hamun". Padahal yang benar dalam bahasa Melayu kata "sumpah serapah" yang dimaksudkan dalam bahasa Indonesia itu

${ }^{39}$ Raja Ali Haji, Kitab Pengetahuan Bahasa, hlm. 197. 57.

${ }^{40}$ Jan van der Putten dan Al-Azhar, Di Dalam Berkekalan Persahabatan, hlm. adalah "sumpah seranah". Begitu pula kata "seronok" yang dalam bahasa Indonesia berkonotasi pada pengertian porno. Padahal dalam bahasa Melayu kata "seronok" sesuatu yang menyenangkan. ${ }^{41}$

\section{Raja Ali Haji dan Pemeliharan Budaya Melayu}

Dalam bidang budaya juga Raja Ali Haji melihat budaya Melayu yang islami sudah mulai diabaikan. Masyarakat Melayu yang berdomisili di Pulau Penyengat mulai terancam pengaruh negatif budaya Barat (Eropa) yang ditebar di Singapura. ${ }^{42}$ Masuknya budaya asing mempercepat proses pengikisan terhadap nilai-nilai budaya luhur Melayu yang dianut selama ini. Raja Ali Haji merasakan bahwa masuknya kebudayaan Barat dan nilai-nilai asing yang tidak islami, jelas menimbulkan tantangan bagi masyarakat Melayu. Peran untuk mengeliminir dan melakukan filterisasi inilah yang selalu diwantiwantikannya. Ia meyakini bahwa perubahan terhadap adat istiadat tradisional akan berakibat kerusakan terhadap masyarakat serta mempercepat pengikisan niali-nilai lama yang luhur dan agung. Sikap dan pandangan serta perannya dalam mempertahankan agama dan budaya Melayu tersebut diamati oleh Residen Eliza Nitscher. Dalam

${ }^{41}$ Lihat, Hasan Junus, Raja Ali Haji Budayawan di Gerbang Abad XX, hlm. 120; Barbara W. Andaya \& Virginia Matheson, Islamic Thougth and Malay Tradition - Writing of Raja Ali Haji of Riau, hlm. 123; lihat juga, Taufik Ikran Kamil, "Pandangan Raja Ali Terkini", Makalab Hari Raja Ali Haji, 1-31 Oktober 1996, hlm. 8.

${ }^{42}$ Menurut Hasan Junus, sebagaimana dikutip oleh Taufik Ikram Jamil, pada pertengahan abad ke-19 Singapura mulai mendominasi perdagangan di Selat Malaka, jauh meninggalkan Riau dan Pulau Pinang. Mislanya, pada tahun 1830-an hasill perdagangan Singapura melonjak tajam menjadi 2,7 juta pound, sementara Riau hanya 300 ribu pound, dan Pulau Pinang sebanyak 1 juta pound. Taufik Ikran Kamil, Pandangan Raja Ali Terkini”, hlm. 3. Dari data tersebut, dapat dipaham kalau Singapura menjadi kota yang menggiurkan untuk menjadi tempat bersenangsenang. Tubfat al-Nafis menjelaskan betapa Sultan Mahmud yang masih muda acap kali menyeberang ke Singapura untuk memperturutkan hawa nafusnya dan mengunjungi tempat-tempat yang tidak patus bagi seorang terhormat. Lihat, Raja Ali Haji, Tubfat al-Nafis, hlm. 352-353 dan 356-357. 
laporan pensiunnya, melukiskan tentang sosok figur Raja Ali Haji secara keliru, demikian:

Raja Ali Haji sebagai "seorang terpelajar yang sangat fanatik, orang yang benar-benar mengharapkan lenyapnya umat Krisiten, perasaan bukan main bangga terhadap keturunan Bugisnya, dan menentang dengan sengit perubahan dalam adat Melayu tradisional, Raja Ali Haji bersifat antagonistic terhadap kehadiran Belanda dan "bukan sahabat bagi orang Eropa."

Ungkapan Residen Belanda Eliza Nitscher, seperti yang dikutip di atas, hemat penulis, tidaklah seluruhnya benar. Ungkapan bahwa Raja Ali Haji, "bukan kawan bagi orang Eropa" itu harus dilihat dari kaca mata politik kepentingan kolonial pemerintahan Hindia Belanda yang tetap ingin melanggengkan tancapan kuku kekuasaan penjajahannya. Pandangan negatif Eliza Nitscher terhadap Raja Ali Haji, menurut Al Azhar, boleh jadi tersebar dan dipercayai oleh kalangan pegawai pemerintahan Hindia Belanda di Batavia, karena dalam kapasitasnya sebagai Residen Riau. Lagi pula, Nitscher sendiri dianggap memiliki wibawa ilmiah karena semasa di Batavia, sebelum diangkat Residen di Riau, ia terlibat dalam lingkaran Bataviaasch Genootschap, bahkan pernah menjadi sekretaris lembaga tersebut. ${ }^{44}$

Padahal, sesungguhnya Raja Ali Haji termasuk pemeluk agama Islam yang inklusif dan toleran terhadap orang-orang Kristen. Ini misalnya dapat dibuktikan dengan cukup banyakanya ia mempunyai kawan dari orang Eropa, terutama dari kalangan intelektual BaratKristen, namun bukan dari kalangan politisi Belanda yang tendensius. Persoalan politis itu memang menjadi sebab utama dimana penilaian negatif terhadap dirinya, seperti dari kutipan di atas, biasa timbul. Hal ini dipertegas, misalnya ungkap U.U. Hamidi, dimana posisi Raja Ali Haji, yang tentu saja berpihak kepada raja-raja Melayu Riau yang

${ }^{43}$ Barbara W. Andaya \& Matheson, Islamic Thougth and Malay Tradition - Writing of Raja Ali Haji of Riau, hlm. 114.

${ }^{44} \mathrm{Al}$ Azhar, "Raja Ali Haji: Sebuah Ziarah", dalam Jurnal Filologi Melayu, Jilid 4, Kuala Lumpur: Perpustakaan Negara Malaysia, 1995, hlm. 45. konfrontatif terhadap penjajah (Belanda dan Inggris). Sehingga adalah logis, kalau pihak penjajah tidak senang kepadanya. ${ }^{45}$ Dan kalau ditilik dari karya-karyanya tidak satupun yang berpihak dan menguntungkan serta memuji pihak penjajah Belanda. Sehingga mudah dipahami kalau ia disiyalir sebagai "bukan kawan bagi orang Eropa". Berbeda, misalnya dengan Abdul Kadir Munsyi dalam karya-karya selalu memuji "orang kulit putih" sebagai sahabat dikasihi. ${ }^{46}$

Pandangan Eliza Nitscehr yang tidak simpati ini adalah wajar karena, menurut Jan van der Putten, ia memiliki "a personal dislike." dengan Raja Ali Haji. Sikap permusuhan Nestscher juga ia nyatakan bahwa Raja Ali Haji adalah penghasut berkembangannya ketegangan antara sultan yang berkedudukan di Lingga dan Yang Dipertuan Muda yang berkedudukan di Pulau Penyengat. Bahkan ia menuduh bahwa Raja Ali Haji bertujuan agar Riau (YDM Bugis di Penyegat) menjadi sebuah negeri merdeka yang terpisah dari Lingga (Sultan Melayu di Lingga). ${ }^{47}$ Seseungguhnya Raja Ali Haji tidak pernah secara terbuka mendukung golongan orang Bugis terhadap golongan orang Melayu. Ia memiliki pertimbangan bahwa orang Bugis, pada masa hidupnya, sudah menjadi bagian dari dunia Melayu. Baginya, orang Bugis adalah sebuah elemen yang kehadiran dan kedudukannya diakui, tetapi dalam

45 Jika dibandingkan antara Raja Ali Haji dengan Abdullah Munsyi dalam bahasa (dan sastra), maka yang disebut terakhir ini, oleh kalangan tertentu lebih mendapat apresiatif. Apa sebabnya? Paling tidak, menurut U.U. Hamidi, ada kaitannya dengan persoalan politis. Bahwa Raja Ali Haji adalah seorang bangsawan kerajaan yang selalu mengambil jarak dengan pihak politis penjajah Belanda dan Barat pada umumnya. Sedangkan Abdullah Munsyi, selalu memuji "orang putih" sebagai sahabat yang dikasihi. Akibatnya Abdullah, sangat disayangi oleh kolonia Belanda apa lagi Ingggris. U.U. Hamidi, Bahasa Melayu Riau, (Pekan Baru: Badan Pembinaan KesenIan Daerah Propinsi Tk. I Riau), hlm. 34-35.

${ }^{46}$ U.U. Hamidi dan Muchatar Ahmad, Beberapa Aspek Sosial Budaya Daerah Riau, (Pekanbaru: UIR Press, 1993), hlm. 23.

47 Jan van der Putten dan Al-Azhar, "Introduction" dalam Di Dalam Berkekalan Persababatan, hlm. 57. 
waktu yang bersamaan mereka sudah terintegarsi sepenuhnya, bahkan mereka juga mengakui dirinya sebagai Melayu keturunan Bugis. ${ }^{48}$

Memang benar Raja Ali Haji berketurunan orang Bugis, tetapi sebagai orang Melayu ia berjuang untuk memelihara adat, bahasa dan budaya Melayu. Kalau Raja Ali Haji berjuang untuk melegitimasi kehadiran orang di dunia Melayu, Jan Putten, kenapa ia tidak kembali kepada latarbelakang suku yang dimilikinya, dan mempelajari bahasa, budaya dan tradisi Bugis? Jika benar-benar ia merasa sebagai berketurunan Bugis, jika ia tidak menganggap dirinya seorang Melayu "asli", kenapa ia sedemikian menekankan tentang penciptaan bahasa dan Budaya Melayu “murni”?49 Pertanyaan-pertanyaan Jan Puttten, langsung atau tidak, telah menjawab tuduhan Netscher terhadap Raja Ali Haji di atas.

Kekeliruan E. Nitscher bahwa Raja Ali Haji, "bukan sahabat bagi orang Eropa", tidak benar. Buktinya Raja Ali Haji dapat bergaul dengan pembesar-pembesar dan berkawan dengan sarjana-sarjana Eropa, bahkan salah seorang diantaranya, von de Wall, sedemikian akrabanya, ${ }^{50}$ bahkan ia telah menganggapnya sebagai saudara, ${ }^{51}$

48 Lihat, Jan van der Putten, “A Malay of Bugis Ancestry: Haji Ibrahim's Strategies of Survival", Journal of Southeast AsIan Studies, Vol. 32, No. 3, October 2001, hlm. 345 [dan juga catatan kaki no. 9]; Jan van Putten ini, dalam Timothy P. Beernard (ed.), Contesting Malayness: Malay Identity Across Boundaries, Singapore: Singapore University Press, tt., hlm. 122-3

49 Lihat, Jan van der Putten, “A Malay of Bugis Ancestry: Haji Ibrahim's Strategies of Survival", 122-123.

${ }^{50}$ Keakraban Raja Ali Haji dengan sahabatnya, van de Wall tidak saja diakuinya, tetapi juga dirasakannya, seperti ia tuangkan dalam suratnya, "bahwa sesungguhnya kita menerima kasihlah kepada sahabat kita dengan beberapa banyak serta beberapa kali. Kita menyusahkan sahabat kita dengan beberapa kali hajat, padahal sahabat kita sabar serta disampaikan hajat kita. Syahdan yang kita memberitahu kepada sahabat kita hal diri kita, yang selama2 ini banyak juga berkenal2 dengan orang putih dan orang besar yang sudi2 berkenal-kenalan dengan kita, akan tetapi boleh sahabat kita siasat, belum pernah kita membanyakkan haja dengan permintaan dan lainnya. Aníllala sahabat kita seorang saja yang kita banyak berbuat manja. Sebab kita lihat sahabat kita banyak ikhlas dengan kita, jadi hilang 202 sehingga Raja Ali Haji merasa tidak sungkan untuk menyingkap tabir rasa "kemaluannya" 52 dengan menceritakan hal-hal yang sangat pribadi (rahasia) mengenai dirinya kepada sahabatnya tersebut, seperti kondisi ekonominya, ${ }^{53}$ dan pengalaman seksul di hari tuanya. ${ }^{54}$ Akan

malu kita, serta kita harap berkekalan perikatan sahabat antara sahabat kita dengan kita selama2nya, serta berbanyak2 maaf di atas kita apa2 yang terlebih dan terkurang daripada adab bahasa kita kepada sahabat kita adanya. Seperti kata Arab, al-rafíqu l-sâlih yuwassi'u l-qalba l-talih, yakni 'tolan yang baik itu meluaskan hati yang tiada baik'. Intaha." Jan van der Putten dan Al-Azhar, Di Dalam Berkekalan Persababatan, hlm. 36-37.

51 “.... Itupun daripada sanga ikhlas serta putih hati kita kepada paduka sahabat kita maka kita terangkan hal kita ini, karena pada perasaan kita yang sahabat kita itu saudaralah kepada kita. Pasti sahabat kita tutup juga mana2 jadi kemaluan atas kita adanya." ." Jan van der Putten dan Al-Azhar, Di Dalam Berkekalan Persababatan, hlm. 55.

${ }^{52}$ Kata "kemaluan" di sini bukan bermakna seperti yang dipahami dewasa ini, berkonotasi kepada "alat kelamin" baik laki-laki maupun permepuan. Akan tetapi makna "kemaluan" di isni tetap meruju kepada makna "aslinya" sesuai dengan maksud pada zamanya, seperti yang dikehnedaki oleh Raja Ali Haji sendiri, yaitu lebih bermakna "aib", misalnya Raja Ali Haji sering menggandengkan kata tersebut dengan "menutup kemaluan". Mislanya, lihat surat Raja Ali Haj tertanggal, 22 April 1862; dan 7 Desember 1866. Jan van der Putten dan Al-Azhar Di Dalam Berkekalan Persababatan, hlm. 55 dan 65.

${ }^{53}$ Raja Ali Haji, mislanya menceritakan tentang kondisi keuangannya kepada sahabatnya yang selalu tidak mencukupi. Sehingga uang yang dipinjam dari sabatanya sebesar 50 rupiah belum dapat ia lunasi. [surat tertanggal, 15 April 1862, Putten Al Azhar, hlm. 54]. Kondisi ekonomi satu dekade dikahir kehidupannya dirasakannya begitu berat, karena sedemikian besar tanggungan Raja Ali Haji untuk menghidupi keluaraga besarnya yang, disebutnya sendiri, "adalah ahli2 kita serta anak2 cucu kita saerta khadam2 kita ada enam puluh tujuh orang, dan uang belanja2 kita dua ratus rupiah.” Meskipun sebagai anggota kerajaan, ia memperolah setiap bulan dari YDM Riau atas pengasilan negeri dari pemerintahan Belanda, tetapi tetap saja tidak mencukupi. Apa lagi, YDM merencanakan mengurang membagian yang akan diterimanya dari kerajaan. [Surat tertanggal 22 April 1862, Putten \& Al Azhar, hlm. 55]. Kemudian, Raja Ali Haji berharap agar sahabatnya berkenan untuk memberikan uang pada bulan ini sebanyak 45 ringat, sisanya pada bulan depan 15 ringgit. (Sepertinya dalam membatu sahabatnya menyusun kamus, Raja Ali Haji mendapat honor 30 ringgit setiap bulannya dari Von de Wall). Raja 
tetapi, menurut T. Iskandar, para sarjana dan pembesar Barat itu tidak terlalu berpengaruh terhadap dirinya. Sungguhpun begitu, ia tetap dapat menghargai nilai-nilai peradaban Barat, tetapi nilai-nilai tersebut menurutnya tidak sesuai bagi masyarakat Melayu. Karenanya, ia tetap teguh pada pendiriannya itu, sekaligus mempertahankan dengan sungguh-sungguh nilai-nilai budaya dan adat Melayu. ${ }^{55}$

Ali Haji meminta 45 ringgit pada bulan itu karena ia memerlukan biaya untuk memperingati maulid Nabi, "hendak menyuruh pergi ke Selat mencari sedikit2 makan-makanan dan barang2 yang patut" [Surat tertanggal 30 Mei 1869, Putten \& Al Azhar, hlm. 83]. Pada kesempat lain, Raja Ali Haji berharap "uang pertolongan" itu ditambah 10 ringgit, “... sebab kita sekarang tiada lagi daripada pendapat lain2.” [Surat tertanggal, 24 Desember 1869, Putten \& Al Azhar, hlm. 89]. Ketika hendak mengkhitan anaknya, Husin, Raja Ali Haji tidak merayakan secara besar-besaran, karena “... kita terlalu picik daripadi rezeki. Bukannya seperti yang telah lalu. Daripada tahun yang lepas2 ada juga yang lebih2 sedikti daripada hajat, yang diambil daripada pulau2 Karimun dan Kundur." Sekarang kedua pulau tidak lagi memproduksi tambang timah karena terlalu besar biaya oprasionalnya. [Surat tertanggal, 1 September 1870, Putten \& Al Azhar, hlm. 89, 193 dan 203]. Setiap kali Raja Ali Haji menyapaikan kondisi ekonominya dan berharap "uang pertolongan” itu untuk dirahasikan. “... Inilah rahasia kita. Janganlah orang2 tahu kedaifan kita. Memadailah paduka sahabat seorang sahaja yang tahu supaya kita tiada mendapat malu adanya." Jan van der Putten dan Al-Azhar, Di Dalam Berkekalan Persahabatan, hlm. 83.

54 Ia mengeluh dengan menceritkan problem pribadinya tentang kondisi "lemah syahwat" yang dialaminya, dan memohon kepada sahabatnya untuk dicarikan solusinya, kemungkinan ada obat dari dokter. Dan ia bertambah susah karena baru saja mendapatkan seorang gundik muda. Suratnya [tertanggal, 31 Juli 1972] berbunyi, diantaranya: "Ini satu susah, akan tetapi rahasia kitalah kepada paduka sehabat kita, yaitu syahwat kita inilah yang kurang benar2. Allah Allah, tiadakah obat daya upaya dokter di situ lagi. Sebab kita jika sudah rusak ini apa gunanya lagi dunia ini. Jadi susuh kita, lebih daripada susahkan penyakit. Bagaimanakah kiranya ikhtiar paduka sahabat kita memberi ikhtiar kepada kita. Istimewa pula ini baharu pula kita dapat satu gundik budak muda. Maka hal kita inilah, itulah yang susuh kita. Putten dan Al-Azhar, Di Dalam Berkekalan Persababatan, hlm. 115.

${ }^{55}$ Dalam hal ini, Raja Ali Haji berbeda dengan Abdullah bin Abdullah Kadir Munsyi yang, menurut R. Roolvink, sebagaimana dikutip oleh T Iskandar, telah berada di perbatasan antara kebudayaan Timur dan Barat. Abdullah telah keluar 204
Bahkan secara khusus, Raja Ali Haji mengkritik mereka yang suka memakai pakaian ala Inggris, Belanda, atau Cina: memakai celana, baju, kaos kaki dan sepatu. Dalam pandangan Raja Ali Haji pakaian orang asing tersebut tidak layak dan sesuai bagi orang Melayu. Sebaliknya, menurut pengakuannya, pakaian Melayu "pada penglihatan mataku sangatlah tampan, orang-orang Melayu memakai cara Melayu yang dulu-dulu, tiada bengis rupanya. Adapun sekarang ini yakni, waktu masa aku mengarang kitab ini, maka tiadalah aku lihat lagi pakaian orang Melayu seperti pakaian adat-istiadat lama."56 Sesungguhnya, kritik Raja Ali Haji terhadap masyarakat Melayu yang ingin "menyerupai" tidak terlalu ditekankan pada "makna lahiriahnya" (baca: memakai pakai ala bangsa Asing, seperti celana, baju dan sepatu). Akan tetapi, kritiknya itu lebih ditekankan pada "makna bathiniahnya" (baca: menghilangkan indentitas dan budaya dan adat Melayu yang luhur dan agung). Karena, menurut Raja Ali Haji, mereka memakai pakaian asing tersebut dengan tujuan, "supaya di malam hari orang tidak mengenal mereka sebagai orang Melayu”.57 Pandangan Raja Ali Haji terhadap budaya dan tradisi Melayu diekspresikan tidak hanya sebagai pembelaan terhadap sikap dan tingkah laku yang mencirikan "Melayu". Akan tetapi, lebih dari itu sebagai sebuah dalih agar penegakkan moral sosial kerajaan dipertahankan. Apabila masyarakat senantiasa menuruti kebiasaan untuk bertingkah laku yang patut, maka hubungan yang harmonis antara manusia dengan manusia,

dari lingkungan dan budaya masyarakatnya, meskipun demikian ia belum sepenuhnya berada dalam lingkungan kebudayaan Barat. T. Iskandar, "Raja Ali Haji Tokoh dari Pusat Kebudayaan Johor-Riau", dalam Muhamad Daud Muhamad (ed.), Tokoh-tokoh Sasera Melayu Klasik, Kuala Lumpur: Dewan Bahasa dan Pustaka, 1987, hlm. 139.

${ }^{56}$ Raja Ali Haji, Kitab Pengetahuan Bahasa, hlm. 197.

57 Raja Ali Haji, Kitab Pengetahuan Bahasa, hlm. 197. Jauh sebelumnya, diperingatkan al-Ghazali: pakaian adalah untuk menutup "telaniang" dan bukan untuk menyembunyikan identitas seseorang dan 'sembunyilah dihadapan makhluk, sehingga kamu menyeleweng. Barbara Andaya dan Matheson, Islamic Thougth and Malay Tradition - Writing of Raja Ali Haji of Riau, hlm. 123. 
masyarakat dengan penguasa, dan manusia dengan Tuhan, akan tercapai dengan sendirinya. ${ }^{58}$

Upaya Raja Ali Haji dan "lingkaranya", meminjam istilah Al Azhar, ${ }^{99}$ serta generasi-generasi berikutnya dalam memelihara dan membina bahasa Melayu Riau, ${ }^{60}$ telah melapangkan jalan terbentuknya bahasa nasional, bahasa Indonesia. Menurut U.U. Hamidi, upaya Raja Ali Haji dalam membina dan memelihara bahasa Melayu Riau ini, "bagaikan mengapak dan menarah, sehingga akhirnya mempunyai bentuk dan dasar yang baik. Kemudian setelah bahasa Melayu itu menjadi bahasa Indonesia, upaya membinaan bahasa itu hanyalah bagaikan mengetam."61 Maka tidak berlebihan kalau dikatakan, tanpa upaya "pengetaman" Raja Ali Haji dan "lingkarannya", "Sumpah Pemuda" boleh jadi tidak/belum diikrarkan tahun 1928. Atau setidaktidaknya, bahasa Indonesia belum menjadi bahasa kebangsaan, lantaran genarasi bangsa saat itu baru pada tahap "mengapak" dan belum "mengetam". Kalau melihat perjuangan Raja Ali Haji dalam membina bahasa dan membela budaya Melayu pada khususnya, dan membela kebenaran pada umumnya lawat "kekuatan kalam", sangatlah tepat kalau anugerah gelar Pahlawan Nasional disandangnya.

58 Virginia Matheson, "Strategies of Survival: The Malay Royal Line of Lingga-Riau", Journal of Southeast AsIan Studies, Vol. XVII, No. 1, March 1986, hlm. 6; lihat juga, Barbara W. Andava \& Virginia Matheson, hlm. 127.

59 Al Azhar, "Jalan Bahasa dan Lingkaran Raja Ali Haji", Makalah Dialog Selatan II, Dewan KesenIan Riau (DKR), Pekanbaru, 11-13 Desember 1995.

60 Upaya yang dilakukan Raja Ali Haji dalam membina bahasa dan pemeliharan budaya Melayu dengan melahirkan dua karyanya, Bustan al-Katibin dan Kitab Pengetahuan Bahasa, belakangan mempengarhui generasi setelahnya dan sekaligus melanjutkan upanyanya. Misanya, Raja Ali Haji Kelana melahirkan karya dalam bidang ini, yaitu Bughyat al-Ani fi Huruf al-Ma'ani; Abu Muhammad Adnan dengan karyanya, Pembuka Lidah degan Teladan Umpama yang Mudablm. Hasan Junus, Raja Ali Haji dan Karya-karyanya, hlm. 148.

${ }^{61}$ U. U. Hamidi, "Hilang Jasa Kapak Oleh Jasa Ketam: Peranan Raja Ali Haji dalam Perwujudan Bahasa Indonesia" dalam Teks dan Pengarang di Riau, (Batam: Cindai Wangi Publishiong Kerjasama Yayasan Adhi Karya IKAPI dan The Ford Foundations, 2003), hlm. 8.
Sekurang-kurangnya, dengan penganugrahan gelar Pahlawan Nasional tersebut, bangsa ini membayar kesalahannya, tidak lagi, meminjam ungkapan U.U. Hamidi "hilang jasa kapak oleh jasa ketam”. ${ }^{62}$

62 Perjuangan yang diupayakan oleh Pemerintah Kota Tanjung Pinang pada khususnya, dan Masyarakat (Kepulauan) Riau pada umumnya untuk mengusulkan pengangtkatan Raja Ali Haji sebagai Pahlawan Nasional telah membuahkan hasil. Kini Raja Ali Haji telah mengikuti jejek kakeknya, Raja Haji dan dua tokoh pejuang Melayu lainnya, Tuanku Tambusai dan Sultan Syarif Qasim II yang sebelumbya telah diangkat menjadi Pahlawan Nasional dari bumi Melayu-Riau. Akan tetapi, dibandingkan dengan tiga pahlawan nasional sebelumnya dan pahlawan secara keseluruhan, pengangkatan Raja Ali Haji memiliki makna yang relatif berbeda. Makanya, ketika membaca tantang pengusulan Raja Ali Haji jadi pahlawan nasional oleh pemerintah kota Tanjung Pinang kepada pemerintah pusat (29 Maret 2004), saya bergumam: "gagasan cerdas sekaligus unik dan menarik". Disebut "cerdas" karena gagasan ini menggeser, untuk tidak mengatakan "menyalahi", defenisi konvesional term pahlawan. Selama ini, term pahlawan didefinisikan sebagai sosokfigur yang gagah berani dan/atau berjasa dalam membela dan membertahankan negara dari serangan musuh (luar). Artinya, defenisi semacam ini stressing pointnya lebih pada perjuangan fisik (jihâd) serta beroreintasi pada "kekuatan pedang". Sebaliknya, lewat gagasan pengusulan Raja Ali Haji jadi pahlawan nasional, definisi pahlawan bergesar dan lebih menitikberatkan pada perjuangan secara non-fisik (ijtibâd) serta beroreintasi pada "kekuatan kalam". Kelanjutan dari di atas, disebut sekaligus "unik" karena, sepanjang pengetahuan penulis, selama ini penganugerahan gelar pahlawan nasional kepada seseorang melulu dengan pertimbangan jasa besarnya dalam "kekuatan pedang." Sebaliknya, lagi-lagi, sejauh yang diketahui, penganugrahan gelar pahlawan nasional kepada seseorang dengan pertimbangan jasa agungnya dalam "kekuatan kalam" tidak/belum pernah ada. Dan tambah pula, keunikan itu jatuh pada anak jati diri figur intelektaul MelayuRiau, Raja Ali Haji. Disebut "menarik" karena dewasa ini defenisi konvensional term pahlawan dengan "kekuatan pedang" semakin menyempit ruangnya karena musuh yang akan dihadapi oleh negara/bangsa bukan lagi serangan musuh dari luar secara fisik/ senjata. Maka kalau definisi ini dipertahankan dalam konteks kekinian dan kedisinian, niscaya lambat-laun akan kehilangan relevansi dan salahsalah bisa out to date (kadaluarsa). Sebaliknya, definisi alternatif term pahlawan dengan "kekuatan kalam" untuk kurun waktu mendatang akan semakin meluas ruangnya karena musuh yang akan dihadapi adalah panetrasi budaya dari luar yang sangat mungkin bertentangan budaya luhur kita. Maka definisi term pahlawan 


\section{Prinsip Dasar Pemeliharaaan Bahasa dan Budaya}

Pemeliharan budaya dan membinaan bahasa Melayu telah dilakukan oleh Raja Ali Haji, setidak-tidaknya, dilandasi dua prinsip dan pandangan yang berorientasi masa depan. Pertama, "Jika hendak mengenal orang yang berbangsa, lihat kepada budi bahasa", sebagaimana ia gubah dalam Gurindam Dua Belas. ${ }^{63}$ Sikap dan pandangan yang dimiliki Raja Ali Haji ini, menurut U.U. Hamidi, menghilhami dan membangkitkan semangat generasi anak-cucu Raja Ali Haji untuk membangun kesadaran akan arti penting pemiliharaan bahasa dan budaya Melayu. ${ }^{64}$

Kedua, bahwa dalam memelihara dan pelestarian ilmu pengetahuan lebih baik dilakukan dalam bentuk tradisi tulis, dan bukan dalam bentuk tradisi lisan. Prinsip dan pandangan Raja Ali Haji ini, menurut Matheson, menjadi daya dorong baginya untuk melahirkan karyanya, Bustan al-Kitabin dan Kitab Pengetahuan Bahasa. Begitu pula, produktifitasnya dalam melahirkan karya tulis dari berbagai aspeknya, seperti aspek syair/sastera, sejarah, politik dan agama, khususnya aspek budaya dan bahasa, menurut Matheson, menunjukan prinsip dan pandangannya ini. ${ }^{65}$

semacam ini di masa-masa mendatang niscaya akan semakin relevan dan up to date. Artinya, dalam menghadapi musuh yang disebut belakangan ini (panetrasi budaya asing yang bertentangan dang budaya Melayu) tidak bisa dilawan dengan "kekuatan pedang", tetapi harus dihadapi dengan "kekuatan kalam". Sikap dan pandangan seperti ini adalah cerminan dari ungkapan indah Raja Ali Haji: "Segala pekerjaan pedang itu boleh dibuat dengan kalamadapun pekerjaan kalan itu tiada oleh dibuat dengan pedang dan beberapa ribu dan laksa pedang yang sudah terbunus dengan segores kalam jadi tersarung." Ali M. Hassan Palawa, "Raja Ali Haji: Pahlawan Nasional Lewat Kalam," Riau Pos, 2004.

${ }^{63}$ U.U. Hamidi, "Hilang Jasa Kapak Oleh Jasa Ketam: Peranan Raja Ali haji dalam Perwujudan Bahasa Indonesia" dalam Teks dan Pengarang di Riau, hlm. 18-19, U.U. Hamidy, Riau Sebagai Pusat Bahasa dan Budaya, (Pekanbaru: UNRI Press, 2003), hlm. 41.

${ }^{64}$ U. U. Hamidi, "Hilang Jasa Kapak Oleh Jasa Ketam, hlm. 18.

65 Menurut Matheson, upaya Raja Ali Haji dalam memelihara dan membina budaya dan bahasa telah menjadi alas dasar yang kokoh bagi pembentukan tradisi
Prinsip Raja Ali Haji untuk memelihara dan mempertahankan bahasa dan budaya lewat tradisi tulis sudah diperjuangkan semasa hidupnya pada 1862 agar pemerintah Belanda menyediakan "perkakas"/mesin cetak ${ }^{66}$ tipografi yang lebih canggih, ${ }^{67}$ meskipun sebelumnya di Riau sudah ada mesin cetak litografi pada 1858.68 Raja Ali Hai Haji lebih menginginkan percetakan tipografi yang, menurutnya, hasilnya sangat baik dan rapi. Karenanya, ia sangat mengagumi hasil cetakan tipografi, sebagaimana ia lihat dari bukubuku terbitan di Bativia. ${ }^{69}$ Akan tetapi, keinginan Raja Ali Haji itu baru

intelektual Melayu modern. Sikap Raja Ali Haji dalam menghargai budaya Melayu tradisional dan sekaligus pemamfaatan kaedah yang benar dan tepat menunjukkan ia sebagai "orang tengah" antara dunia tradisi dan dunia modern. Virginia Matheson Hooker, "Pengenalan" Dewan Bahasa dan Pustaka, 1998, hlm. xiii.

${ }^{66}$ Ada beberapa term dipergunakan Raja Ali Haji yang diasosiasikan dengan peercetakan, yaitu kata "cetak", "cap", "tera" dan "tab". Lihat, Jan van der Putten, "Printing in Riau: Two Staps Toward Modernitiy", dalam Cyinthia Chou and Will Derks, Riau in Transition, Deel 153, 1997, hlm. 727; lihat juga, Jan van der Putten dan Al-Azhar, Di Dalam Berkekealan Persababatan, hlm. 48.

67 Upaya Raja Ali Haji mengadakan percetakan ini di usulkan dan dibicarakan kepada Eliza Netscher (1861-1870). Bersama dengan Engku Haji Ibrahim, ia menghadap residen. Residen meminta Raja Ali Haji untuk menghitung anggaran dananya. , "Maka tuan residen bersabda kepada kita, suruh hitung kira2 belanja cetak...” [surat Raja Ali Haji, tertanggal, 22 April 1862]. Setelah dihituang dana aggaran pengadaan percetakan itu, rancangan anggaran tersebut ia dititipkan kepada Haji Ibrahim untuk diserahakan kepada sahabatnya, van de Wall. Raja Al Haji berharap kepada sahabatnya, von de Wall, dalam kapasitas sebagai Waki Residen Riau, agar ranacangan anggaran tersebut diteruskan kepada Residen Riau. Akan tetapi, mungkin anggarannya cukup besar karena Raja Ali Haji menginginkan percetakan yang lebih bagus dari percetakan yang telah ada di Pulau Penyengat, sehingga, sepertinya usulan Raja Ali Haji untuk pengadaan percetakan belum dipenuhi oleh pemerintahan Belanda. Jan van der Putten dan Al-Azhar, Di Dalam Berkekalan Persahabatan, hlm. 54. Jan van der Putten, "Printing in Riau: Two Staps Toward Modernitiy, hlm. 725 ${ }^{68} \mathrm{Ibid}$., hlm. 721.

${ }^{69}$ Ibid. 
terwujud sepeninggalannya, masa Sultan Sulaiman (18571882) di Lingga yang dipergunakan untuk mencetak karya-karyanya. ${ }^{70}$

Dalam suratnya kepada Haji Ibrahim, Raja Ali Haji menyampaikan arti penting percetakan ("perkakas"/mesin cetak tipografi), sekaligus mengeluhkan sulitnya proses-proses kerja yang harus dilalui dalam melahirkan karya tulisan dan biaya penyalinan naskah yang harus ia keluarkan:

Adapun pasal pekerjaan berkehendakkan cap karena kami sudah pikir, jika dengan surat tangan karangan itu ada tiga mudaratnya. Pertama, mudarat atas tubuh kami. Sebab kami telah kitab, baru dipikirkan, kemudian baru disurat buram yang pertama, kemudian buram yang kedua, kemudian baru diberikan juru tulis.

Tubuh kami sakit, belanja kami keluar sendiri, satu2 karangan barangkali sekurang-kurangnya enam puluh. Satu karangan itu tiada sudah dengan sebulan dua. Coba awak pikir, satu juru tulis sekurang-kurangnya enam ringgit sebulan. ${ }^{71}$

Perjuangan pengadaan mesin cetak bukan semata untuk kepentingan dirinya dalam melakukan aktivitas kepengarangannya, tetapi juga akan menguntungkan dan mengangkat nama pemerintah Belanda dan Raja-Raja Melayu, seperti kata Raja Ali Haji, "menjadi nama kemuliaan dan faedah kepada pemerintah, serta berhamburan nama itu kepada Raja-Raja Melayu dan lain." 72 Di atas segalanya, menurut Raja Ali Haji, keberadaan percetakan lebih maksudkan untuk kepentingan generasi akan datang:

... yang saya amat sangat harap akan pertolongan tuan atas saya mengikhtiarkan boleh tampak kemuliaan ilmu saya sedikit kadarnya itu kepada segala anak buah saya serta kaum kerabat, karena mereka itu kebanyakan jahil pada ilmu batin dan kemuliaan batin. Maka apabila tampak pada zahirnya maka

${ }^{70}$ Ibid., hlm. 734-735

128.

${ }^{71}$ Jan van der Putten dan Al-Azhar, Di Dalam Berkekalan Persababatan, hlm.

72 Ibid., hlm. 65-66 baharulah mereka itu memuliakan dan membesarkan pada suka menuntut ilmu. Jadilah kemuliaan itu jadi pekakas pada pekerjaan yang am, membaiki yang am. Bukannya semata2 saya sahaja, karena diri saya ini sudah tua, sepatutnya meninggal kasih akan dunia ini, hanyalah yang patut membicarakan mati sahaja. Akan tetapi orang2 yang di belakang saya kelak boleh mengambil ibarat dan teladan, barang yang kebajikan itu mendapat kebajikan jua akhirnya dunia dan akhirat adanya. ${ }^{73}$ [surat Raja Ali Haji, tertanggal, 7 Desember 1866]

Tambah pula, percetakan yang ada pada masa itu sangat membantu dan mendorong kreatifitas dan produktifas dalam melahirkan karya tulis. Maka sepeninggalan Raja Ali Haji lahir sejumlah generasi yang meneruskan pembinaan dan pemeliharahan yang sudah dilakukannya, misalanya Raja Ali Kelana, Raja Ali Khalid Hitam, Raja Abdullah, Syed Syeikh al-Hadi dan lain-lain yang berhimpun dalam organisaisi intelektual, Rusydiah Klab. Pembinaan Usaha yang dilakaukan generasi setelahnya itu sangat menentukan bagi keberhasilan upaya-upaya yang telah dilakukan Raja Ali Haj sebelumnya. ${ }^{74}$

Dalam menyudahi bahasan aspek intlektual Raja Ali Haji dalam bidang bahasa dan budaya, penulis ingin mengutip Hasan Junus yang, secara tidak langsung, merefresentasikan intelektual Melayu-Riau, Raja Ali Haji:

Seorang cendikiawan senantiasa bergelut dengan idea-idea, lalu menuntun masyarakat ke tempat yang sesuai dengan konsep "bahasa" dan kebudayaan Melayu yang mencakup arti akal dan budi pekerti. Tanpa lidah yang fasih ia akan mendapatkan kesulitan menjelaskan gagasan yang hendak ditawarkannya

73 “... yang saya harap akan tuan menolong meikhtiarkan dengan apa2 patu serta lavak, yang saya boleh mendapat satu perkakas yang boleh jadi ringan pada pekerjaan surat2, jika ada tilik pandang belas kasihan raja2 yang besar2 dan adil atas saya, dengan sebab titik lidah perkataan tuan." Ibid.

${ }^{74}$ Hamidy, Riau Sebagai Pusat Bahasa dan Budaya, (Pekanbaru: UNRI Press, 2003), hlm. 41. 
secara jernih dan berkesan. Tanpa hati yang bersih, janganjangan masyarakat yang dituntunya itu dapat terbawa ke arah kerusakan dan keruntuhan. ${ }^{75}$

\section{Kesimpulan}

Dengan lidah fasih yang resonansif, kalam tajam yang produktif; akal cerdas yang mengajari, hati suci yang menghilhami, Raja Ali Haj menuntun masyarakatnya, Melayu menuju jalan yang "lurus" selaras dengan ajaran-ajaran agama dan adat/budaya Melayu yang luhur. Jalan lurus yang telah ditapaki dan ditunjuki Raja Ali Haji ini tidak saja berlaku untuk genarasi pada masanya, tetapi tetap relevan hingga kini, bahkan memiliki resonansi mondial di masa mendatang.

\section{Bibliografi}

Al Azhar dan Elmustian Rahman (peny.), Kandil Akal di Pelatar Budi: Esai dan Renungan Budaya Persembahan Kepada Alm. Raja Hamzah Yusus, (Pekanbaru: Penerbit Yayasan Kata atas kerjasama Masyarakat Pernaskahan Nusantara Riau, 2001).

Al Azhar, "Jalan Bahasa dan Lingkaran Raja Ali Haji", Makalah Dialog Selatan II, Dewan KesenIan Riau (DKR), Pekanbaru, 11-13 Desember 1995.

Ali M. Hassan Palawa, "Raja Ali Haji: Pahlawan Nasional Lewat Kalam,” Riau Pos, 2004.

Barbara W. Andaya \& Virginia Matheson, "Islamic Thougth and Malay Tradition - Writing of Raja Ali Haji of Riau (ca. 1809 - ca. 1873", dalam Perceptions of The Past in Southeast Asia, (Singapura: Heineman Education Book [Asia] Ltd., 1980).

${ }^{75}$ Hasan Junus, Raja Ali Haji: Budayawan di Gerbang Abad XX, hlm. 106-
Harimurti Kridalaksana, "Bustanul Kabitin dan Kitab Pengetahaun BahasaSumbangan Raja Ali Haji dalam Ilmu Babasa", dalam Tradisi Johor-Rian Kertas Kerja Hari Sastra 83, (Kuala Lumpur: Bahasa dan Pustaka, 1987).

Hasan Junus, Raja Ali Haji dan Karya-Karyanya, (Pekanbaru: Pusat Pengkajaan bahasa dan Kebudayaan Riau, 1996).

Hasan Junus, Raja Ali Haji: Budayawan di Gerbang Abad XX, (Pekanbaru: Unri Press, 2002).

Hashim bin Musa, The Bustan al-Katibin and the Kitab Pengetabuan Babasa of Raja Ali Haji of Riau: Establishing the Islamic Scolarly Tradition of Languange Studies in the Malay World", Makalah (belum diterbitkan).

Hendrik Maier, "Raja Ali Haji, Arloji dan Mufassar", dalam Al Azhar dan Elmustian Rahman (peny.), Kandil Akeal di Pelatar Budi: Esai dan Renungan Budaya Persembahan Kepada Alm. Raja Hamzah Yusus, (Pekanbaru: Yayasan Kata kerjasama Masyarakat Pernaskahan Nusantara Riau, 2001).

J. J. de Hollander, Pedoman Bahasa dan Sastra Melayu, (Jakarta: Balai Pustaka, 1984).

Jan van der Putten dan Al-Azhar, "Introduction" dalam bukunya, $D i$ Dalam Berkekalan Persahabatan In Everlasting Friendship Letter From Raja Ali Haji, (Leiden: Departement of Languages and Culture of South-east Asia and Oceania University of Leiden, 1995).

Jan van der Putten, "A Malay of Bugis Ancestry: Haji Ibrahim's Strategies of Survival", Journal of Southeast AsIan Studies, Vol. 32, No. 3, October, 2001.

Jan van der Putten, "On Sex, Drug, and Good Manner: Raja Ali Haji as Lexicographer", Journal of Southeast AsIan Studies, Vol. 33, No. 3, October, 2002. 
Jan van Putten, dalam Timothy P. Beernard (ed.), Contesting Malayness: Malay Identity Across Boundaries, (Singapore: Singapore University Press, tt.).

Mohd. Taib Osman, "Raja Ali Haji: A Figure on Transition or the Last of the Classical Puianggas?", dalam Bunga Rampai: Aspects of Malay Cultures, (Kuala Lumpur: Dewan Bahasa dan Pustaka, 1988).

Peter G. Riddell, "Literal Translation, Sacred Scripture and Kitab Malay", dalam Studia Islamik.a, Vol. 9, no. 1, 2002.

Pieere Labrousse, "Sejarah Kamus Melayu dan Indonesia", dalam Daniel Perret dan Putri Rashidah Megat Ramli, Hubungan Budaya dalam Sejarah Dunia Melayu, (Kuala Lumpur: Dewan Bahasa dan Pustaka, 1998).

T. Iskandar, "Raja Ali Haji Tokoh dari Pusat Kebudayaan JohorRiau", dalam Muhamad Daud Muhamad (ed.), Tokoh-tokoh Sasera Melayu Klasik, (Kuala Lumpur: Dewan Bahasa dan Pustaka, 1987).

T. Iskandar, "Raja Ali Haji: Tokoh dari Pusat Kebudayaan Johor Riau”, dalam Jurnal Dewan Bahasa, Disember 1984.

U. U. Hamidi, "Hilang Jasa Kapak Oleh Jasa Ketam: Peranan Raja Ali Haji dalam Perwujudan Bahasa Indonesia" dalam Teks dan Pengarang di Riau, (Batam: Cindai Wangi Publishiong Kerjasama Yayasan Adhi Karya IKAPI dan The Ford Foundations, 2003).

U. U. Hamidy, Riau Sebagai Pusat Bahasa dan Budaya, (Pekanbaru: UNRI Press, 2003).

U.U. Hamidi dan Muchatar Ahmad, Beberapa Aspek Sosial Budaya Daerah Riau, (Pekanbaru: UIR Press, 1993).

U.U. Hamidi, "Naskah Kuno Daerah Riau: Gambaran Kegiatan Cendekiawan Melayu dalam Bidang Bahasa, Sastra dan
Kemasyarakatan", dalam Masyarakat Riau dan Kebudayaannya, (Pekanbaru: Pemda Tk. I Riau).

U.U. Hamidi, Bahasa Melayu Riau, (Pekan Baru: Badan Pembinaan Kesenian Daerah Propinsi Tk. I Riau, t.th.).

Virginia Matheson, “Kisah Pelayaran ke Riau: Journey to Riau, 1984”, dalm Indonesia Circle No. 36, March 1985.

Virginia Matheson, "Revisting Riau with Knowlwdge: Teaching Text and Concept", dalam Jurnal Filologi Melayu, Jilid 4, (Kuala Lumpur: Perpustakaan Negara Malaysia, 1995).

Virginia Matheson, "Strategies of Survival: The Malay Royal Line of Lingga-Riau", Journal of Southeast AsIan Studies, Vol. XVII, No. 1, March 1986. 